\title{
PENYULUHAN ANEMIA PADA IBU HAMIL DI PUSKESMAS SUKAJADI
}

\section{TAHUN 2014}

\author{
Nur Israyati ${ }^{(1)}$, Yulrina Ardhiyanti ${ }^{(2)}$, Rina Anjelina ${ }^{(3)}$ \\ Email : nurisrayati@nurisrayati@gmail.com
}

\begin{abstract}
Anemia is a decrease in hemoglobin levels found during pregnancy in healthy women who do not experience iron or folate deficiency which is caused by an increase in plasma volume that is relatively greater than the increase in hemoglobin mass and blood cell volume. Approximately $10 \%$ of live births experience postpartum bleeding complications. Approximately $10 \%$ of live births experience postpartum bleeding complications. The most frequent complication of postpartum hemorrhage is anemia. If pregnancy occurs in a mother who is already anemic, postpartum bleeding can aggravate the anemia and can result in death. Counseling activities about anemia in pregnant women was held on Thursday, November 132014 at the Sukajadi Community Health Center which was attended by cadres and local residents. The method used is to provide counseling, handouts, interesting picture and video slides as well as questions and answers about anemia. After this service activity is carried out, it is hoped that pregnant women will be able to understand about anemia in pregnant women, its causes, its effects and how to prevent it.
\end{abstract}

Keywords: Anemia, Pregnant Women

\begin{abstract}
ABSTRAK
Anemia adalah penurunan kadar hemoglobin yang di jumpai selama kehamilan pada wanita sehat yang tidak mengalami defisiensi besi atau folat yang di sebabkan oleh penambahan volume plasma yang relatif lebih besar dari pada penambahan massa hemoglobin dan volume sel darah. Sekitar $10 \%$ kelahiran hidup mengalami komplikasi perdarahan pasca persalinan. Sekitar $10 \%$ kelahiran hidup mengalami komplikasi perdarahan pasca persalinan. Komplikasi yang paling sering dari perdarahan pasca persalinan adalah anemia. Jika kehamilan terjadi pada seorang ibu yang telah menderita anemia, maka perdarahan pasca persalinan dapat memperberat keadaan anemia dan dapat berakibat kematian. Kegiatan penyuluhan tentang Anemia pada ibu hamil telah dilaksnakan pada hari kamis 13 November 2014 bertempat di Puskesmas Sukajadi yang dihadiri kader dan warga setempat. Metode yang dilakukan dengan memberikan penyuluhan, handout, slide gambar dan video yang menarik serta tanya jawab tentang Anemia. Setelah dilakukan kegiatan pengabdian ini diharapkan ibu hamil dapat memahami tentang anemia pada ibu hamil, penyebab, dampak yang ditimbulkan serta cara mencegahnya.
\end{abstract}

Kata Kunci : Anemia, Ibu Hamil 
PENDAHULUAN

Anemia adalah penurunan kadar hemoglobin yang di jumpai selama kehamilan pada wanita sehat yang tidak mengalami defisiensi besi atau folat yang di sebabkan oleh penambahan volume plasma yang relatif lebih besar dari pada penambahan massa hemoglobin dan volume sel darah.

Sebagian besar perempuan mengalami anemia selama kehamilan, baik di negara maju maupun di negara berkembang. Badan Kesehatan Dunia atau World Health Organization (WHO) memperkirakan bahwa 35-75 \% ibu hamil di negara berkembang dan 18\% ibu hamil di negara maju mengalami anemia, diperkirakan 600.000 wanita meninggal dunia setiap tahun akibat komplikasi yang berhubungan dengan kehamilan, persalinan, dan nifas.

Kematian ibu dibagi menjadi kematian langsung dan kematian tidak langsung. Kematian ibu langsung adalah sebagai penyebab komplikasi kehamilan, persalinan, dan nifas, dan segala intervensi atau penanganan tidak tepat dari komplikasi tersebut.

Berdasarkan hasil Survey Demografi Kesehatan Indonesia (SDKI) pada tahun 2012, Angka Kematian Ibu (AKI) di Indonesia meningkat dari 228 per 100.000 kelahiran hidup pada tahun 2007 menjadi
359 per 100.000 kelahiran hidup pada tahun 2013.

Sekitar $10 \%$ kelahiran hidup mengalami komplikasi perdarahan pasca persalinan. Komplikasi yang paling sering dari perdarahan pasca persalinan adalah anemia. Jika kehamilan terjadi pada seorang ibu yang telah menderita anemia, maka perdarahan pasca persalinan dapat memperberat keadaan anemia dan dapat berakibat kematian. Penyakit yang merupakan penyebab tidak langsung antara lain anemia, malaria, hepatitis, dan tuberkulosis. Pada waktu persalinan, diperkirakan ibu kehilangan darah 1.000 ml tetapi tidak mengakibatkan kematian pada ibu sehat, dan apabila terjadi pada ibu anemia, kehilangan darah kurang dari itu dapat berakibat kematian.

Berdasarkan latar belakang yang telah dikemukakan di atas, maka perlu dilakukan penyuluhan yang berjudul "Anemia pada Ibu Hamil di Puskesmas Sukajadi”.

\section{METODE KEGIATAN}

Metode penyuluhan adalah ceramah dan diskusi. Setelah ceramah, maka diberi waktu untuk sesi tanya jawab dan kuis secara lisan serta diskusi sebagai evaluasi pelaksanaan penyululuhan. 


\section{HASIL DAN PEMBAHASAN}

\section{Hasil Pelaksanaan}

Kegiatan penyuluhan tentang anemia pada ibu hamil dilaksanakan pada hari Kamis / 13 November 2014 mulai pukul 08.00-09.00 Wib Kegiatan yang diajarkan kepada peserta atau ibu-ibu ini memberikan hasil sebagai berikut :

1. Meningkatkan pengetahuan dan pemahaman ibu hamil tentang anemia dalam kehamilan.

2. Meningkatkan pengetahuan ibu hamil tentang anemia penyebab, dampak yang ditimbulkan serta cara mencegahnya.

3. Meningkatkan pengetahuan kader tentang anemia dalam kehamilan sehingga kader dapat terus memberikan pelatihan kepada masyarakat yang lain tentang anemia.

\section{PEMBAHASAN}

\section{A. Evaluasi.}

1. Standar Persiapan.
a. Menyiapkan
materi penyuluhan.
b. Menyiapkan tempat.
c. Membagikan leafleat.

2. Standar Proses.
a. Memberi penyuluhan dan menjelaskan materi penyuluhan.

b. Mengevaluasi kehadiran dan keaktifan peserta dari awal sampai akhir.

3. Evaluasi Hasil.

Untuk memberikan informasi tentang anemia pada ibu hamil, penyebab, dampak yang ditimbulkan serta cara mencegahnya.

\section{B. Faktor Pendukung dan}

\section{Penghambat.}

1. Faktor Pendukung.

Sarana dan prasarana yang disediakan serta koordinasi yang baik dengan pihak puskesmas.

2. Faktor Penghambat.

Keterbatasan waktu dalam melakukan penyuluhan yang berkaitan dengan kegiatan pelayanan puskesmas sehingga peserta penyuluhan yang hadir tidak memenuhi target.

\section{KESIMPULAN}

Penyuluhan Anemia pada Ibu Hamil dapat berjalan dengan lancar, meskipun jumlah peserta yang hadir jauh dari target yang diharapkan. Namun, seluruh peserta yang hadir sangat antusias, hal ini dapat dilihat masing-masing peserta mengajukan pertanyaan yang menunjukkan besarnya rasa ingin tahu 
berkaitan dengan materi yang Prawirohardjo, S. (2005). Ilmu disampaikan.

Kebidanan. Jakarta : YBPSP

\section{DAFTAR PUSTAKA}

Prawirohardjo, S. (2008). Ilmu Kebidanan. Jakarta : YBPSP

Varney, Helen. (2001). Buku Saku Bidan.

Cunningham, Gary. F. (2005). Obstetri Jakarta : EGC

Williams. Jakarta : EGC

Fraser M. Diane, Cooper A. Margaret.

(2009). Buku Ajar Bidan. Jakarta :

EGC 